\title{
Hizmet Kalitesi Açısından Üniversitelere Yönelik Şikayetlerin Incelenmesi
}

\section{An Investigation Of The Complaints Made Towards The Universities In Terms Of The Service Quality}

\author{
Ezgi CEVHER, Süleymand Demirel Üniversitesi, ezgicevher@sdu.edu.tr
}

\begin{abstract}
Öz: Yükseköğretim kurumlarında sunulan hizmetlerde, hizmeti alan ve değerlendiren açısından hizmet kalitesinin önemi büyüktür. Yapılan araştırmalarda üniversitelerde hizmetlere yönelik kalite unsurlarından biri de güvenilirlik olarak belirlenmiş, bu konuda "şikayetleri değerlendirme ve sorunları çözme” bir ölçüt olarak kabul edilmiştir. Bu amaçla çalıșmada yükseköğretim alanında faaliyet gösteren kamu ve vakıf üniversitelerine yönelik "şikayetler" araştırlmıştır. Çalışmada, üniversitelere yönelik şikayetlerin içeriğini tespit etmek amaciyla "şikayetvar.com" sitesinde yer alan șikayetler, içerik çözümlemesine göre incelenmiștir. Elde edilen bulgularla șikayetlerin "en fazla hangi alanlarda olduğunu, kamu ve vaklf üniversitelerinin şikayetlerinin karşılaş̧tırlması" amaçlanmış üniversitelerin temel faaliyet alanlarına ve fonksiyonlarına yönelik hizmet kalitesi açısından şikayetlerin içeriği esas alınarak görüş ve öneriler sunulmuştur.
\end{abstract}

Anahtar Sözcükler: Hizmet Kalitesi, Şikayet Yönetimi, Kamu Üniversiteleri, Vakıf Üniversiteleri, sikayetvar.com

\begin{abstract}
In the services provided by the higher education institutions the service quality has great importance in terms of the service fields and the evaluative.. In the conducted studies one of the quality elements for the service in the universities was identified as the reliability, in this issue "handling complaints and solving problems" were adopted as a criterion. For this purpose the "complaints" made for the private and public universities operating within the field of higher education were investigated in this study. In this research, in order to determine the contents of the complaints towards the universities, the complaints which could be found on the site called "şikayetvar.com" were investigated by content analysis. With the obtained findings it was intended to determine that in which field the most complaints were received and to compare the public and the private universities. Opinions and suggestions were presented in terms of the quality of service towards the main operating fields and functions of the universities by taking the content of the complaints as the basis.
\end{abstract}

Keywords: Quality of the service, Complaints management, Public Universities, Private Universities, sikayetvar.com

\section{Giriş}

Ülkemizde yükseköğretim sistemi içerisinde, kamu üniversitelerinin yanında vakıf üniversitelerinin kurulması, bu sisteme rekabetçi olmak adına yeni bir hareketlilik kazandırmıştır. Bu hareketlilik, kamu üniversiteleriyle vakıf üniversiteleri kıyaslandığında, hem aday öğrencilere sunulan seçenekler açısından hem de kaliteli hizmet sunumu açısından rekabetçi bir ortama zemin hazırlamıştır. Bu yüzdendir ki Türkiye' de yeni üniversitelerin kurulması desteklenerek yükseköğretim alanında gelişm sağlanmış, eğitim ve öğretim faaliyetleri geliştirilmiştir.

Yükseköğretim kurumlarında sunulan hizmetlerde, hizmeti alan ve değerlendiren açısından hizmet kalitesinin önemi büyüktür. Sunulan hizmetleri alan ve değerlendiren hedef kitle için "öğrenci, personel, iş dünyası, aileler ve toplum” gibi pek çok gruptan söz edilebilir (Ceylan, 1997: 23-24).Yapılan araştırmalarda üniversitelerde hizmetlere yönelik kalite unsurlarından biri de güvenilirlik olarak belirlenmiş, bu konuda "şikayetleri değerlendirme ve sorunları çözme" bir ölçüt olarak kabul edilmiştir (Owlia ve Aspinwall, 1996: 19). Bu amaçla çalışmanın teorik bölümünde hizmet kalitesi ve yükseköğretimde hizmet kalitesi unsurları konuları ele alınmış, uygulama bölümünde ise yükseköğretim alanında faaliyet gösteren kamu ve vakıf üniversitelerine yönelik "şikayetler" sunulan hizmetleri alanların yorumları dikkate alınarak araştırılmıştır. Elde edilen bulgularla şikayetlerin "en fazla hangi alanlarda olduğunu, kamu ve vakıf üniversitelerinin şikayetlerinin karşılaştırılması” amaçlanmıştır. Ayrıca üniversitelerin temel faaliyet alanlarına ve fonksiyonlarına yönelik hizmet kalitesi açısından şikayetlerin içeriği esas alınarak görüş ve öneriler sunulmuştur.

\section{Hizmet Kalitesi ve Hizmet Kalitesi Boyutları}

Günümüzde müşteriye yönelik sunumda, müşteri güdümlü olmak "her şey müşteriyle başlar" düşüncesinin uygulama biçimidir. Bu düşünceyle örgütler, proseslerini müşteriden gelen tepkilere göre yeniden düzenlemektedirler. Çalışanlara uygulanan ödül ve teşvikler bile müşteri tatmin derecesine bağlanmaktadır. Müşterilere sunulan hizmetlerde siparişe konu olan somut bir ürün bulunmadığından sadece soyut olarak ifade edilen hizmetten söz edilebilir. Dolayısıyla geleneksel verimlilik hesaplamalarında yer alan çıktı/girdi ölçümünden söz etmek doğru olmaz. Bu yüzden, sunulan bir hizmette çıktı kalite algısını değiştirmek ve geliştirmek için girdi kaynaklarında gidilen tercihlere bağlıdır. Bundan dolayı sunulan hizmetlerde kalite ve girdilerin bir arada ele alınması esastır (Demir ve Gümüşoğlu, 1998:218). 
Günümüzde müşteri hizmetlerin kalitesini değerlendirmeden ürün veya hizmet satın almak söz konusu değildir. (Prahalad ve Hamel, 1996: 133) Bu yüzdendir ki, müşteriler ürün veya hizmetleri satın almadan önce gerekli araştırmaları yapmayı tercih etmekte, bunun için daha çok internetten faydalanmaktadırlar. Bu çalışamanın araştırma bölümü de bu düşünce baz alınarak şekillendirilmiştir.

Müşteriye yönelik memnuniyet anlayışına göre, hangi hizmetin kaliteli olduğuna müşteriler karar verir. İşte bu nedenle hizmet kalitesi, müşteriler ile başlar ve müşteriler ile devam eder. Kalitenin yeri, müşterilerin zihnidir. Dolayısıyla örgütler, müşterilerin zihninde güçlü bir kalite algılaması yaratmak zorundadırlar. Hizmet kalitesinin kontrolü de zor bir süreçtir. Hizmet kalitesi boyutuna kavramsal bir bakış açısı geliştiren Parasuraman, hizmet kalitesini müşterilerin hizmetten beklentileri ile hizmete yönelik algılarının bir sonucu şeklinde tanımlamaktadır (Aktaran Devebakan ve Aksaraylı, 2003: 40). 1985 yılında Parasuraman tarafından yapılan çalışmada, hizmet kalitesi ile ilgili olarak on kalite boyutu tanımlanmıştır(Aktaran Çavdar, 2009: 104). Bunlar:

1. Güvenilirlik: Hizmetin güvenilir ve doğru biçimde sunumu, sözlerin yerine getirilmesi anlamındadır.

2. Hizmetin Yeterliliği: Hizmet sunumunda hem örgütsel hem de personel açısından gerekli bilgi ve beceriye sahip olmak demektir.

3. Hizmete Ulaşma: İletişimle ilgili olan taraftır. Hizmete kolay ulaşmayı, bekleme zamanının kısa olmasını, faaliyet saatlerinin uygun olmasını ifade etmektedir.

4. Müşteriye Duyarlılık: Çalışanların, müşterilere zamanında ve yeterli hizmeti vermelerini, müşterilere karşı yardımsever olmalarını ifade etmektedir.

5. Fiziksel Varliklar: Soyut olan hizmetin somut olan fiziksel tarafinı içermektedir. Örgütün sahip olduğu tesisler, çalışanların dış görünüşü, araç gereç ve donanımlar fiziksel olanakları oluşturmaktadır.

6. Örgütün Prestiji: Örgütün müşteride bıraktığı imajın ifadesidir. İnanılırlık, güvenilirlik, dürüstlük, işletmenin ismi, marka tanınırlılığı, çalışanların kişisel özellikleri prestiji oluşturur.

7. Güvenlik:Hem fiziksel açıdan güvenliği hem de mali güvenliği ifade etmektedir. Gizliliği easas alır.

8.Nezaket: Çalışanların müşteriye karşı kibar davranışını, saygısını, sevecen yaklaşımlarını içerir.

9. Müşsteri ile İletişim: Müşteriye sunumda anlamak, dinlemek ve bilgilendirmekle ilgili olan bir kavramdır.

9. Müsşteriyi Bilmek ve Anlamak: Müşteriyi tanımak ve ihtiyaçlarını anlamak adına çabaları barındırır.

Hizmet kalitesinin literatürde yer alan ve tüm örgütlerde kabul edilen boyutları da 5 başlık altında değerlendirilebilir (Zeithaml, Parasuraman ve Berry , 1990: 176) . Bunlar:

1. Fiziksel Özellikler: Fiziksel olanaklar, araş gereç donanımı ifade eder.

2. Güvenilirlik: Hizmetin doğru ve güvenilir şekilde yerine getirilmesi anlamındadır.

3. Heveslilik: Müşterilere yardımcı olma ve destek olma istekliliği ile açıklanır.

4. Güven Olgusu: Çalışanların müşterilerde güven duygusu uyandırabilmesidir.

5. Empati: Müşteri gibi düşünme, müşteriyle kurulan yakın iletişim olarak açıklanabilir.

\section{Yükseköğretimde Hizmet Kalitesi ve Üniversiteler}

Günümüzde eğitim-öğretim hizmetlerinin gelişmesi sonucu yükseköğretimde doğru strateji ve uygulamalarla rekabet sağlanabilir ve uzun vadede yükseköğretim kurumlarının adından söz ettirmesi söz konusu olabilir. Bu yüzdendir ki söz konusu stratejilerde müşterilerin beklenti ve ihtiyaçlarının doğru şekilde tespiti ve karşılanması öncelikler arasındadır. (Hepkul ve Kağnıcıŏlu, 1992).Yükseköğretim denince söz konusu olan hizmet olduğundan hizmetin odağında yer alan hizmet türleri için genel bir sınıflandırma yapmak doğru olmayabilir. Bu doğrultuda hizmetin değerlendiricileri ile hizmetin kendisi de birbirinden ayrılmaz bir bütündür. Bu bakımdan yükseköğretim alanında araştırma yapan araştırmacıların "üniversite değerlendiricileri” adı altında yapmış oldukları çalışmalar bu alana 1şık tutmaktadır. Araştırmacılardan Akao, 1996 yılında yapmış olduğu çalışmasında üniversite değerlendiricilerini "üniversiteden önce, üniversitede ve mezuniyet sonrası" olmak üzere sınıflandırmıştır. Bu sınıflandırmada , üniversiteden önceki grubu; liseler, aileler ve öğrenciler; üniversite dönemindeki grubu; öğrenciler, akademisyenler, yöneticiler ve diğer personel; üniversiteden sonraki grubu ise mezunlar ve sanayi çevresi oluşturmaktadır(Çavdar, 2009: 104-105). Bu taraflar genel olarak üniversitelerin müşterisi konumundadır. Genel anlamda da kaliteli hizmet sunumunda öğrencilere yönelik eğitim programlarında iyileştirilmeye gidilmesi, iç ve dış müşteri memnuniyetinin sağlanması önemlidir. Eğitim kurumlarında müşteri olarak ilk aşamada öğrenciler akla gelmektedir. Ancak kalite anlayışına göre müşteri sadece ürün veya hizmeti tüketen, satın alan kişi veya kuruluşlar değildir. Aynı zamanda kurum içinde birbiriyle ilişki içinde olan ve iş yapan kişiler, çalışanlar, yöneticiler olabilmektedir. Dolayısıyla Akao’ nun araştırmasında bahsettiği ve üniversiteyi üç yönden değerlendirenler iç ve dış müşteriler olarak ifade edilebilir. $\mathrm{Bu}$ yüzden eğitim kurumları açısından müşterileri "öğrenciler, akademik personel, diğer çalışanlar, iş dünyası, aileler ve toplum” gibi ifade etmek mümkündür. Burada, öğrenciler, akademik personel, çalışanlar ve yöneticiler iç müşteriyi, iş dünyası aileler ve toplum da dış müşteriyi oluşturmaktadır. (Ceylan, 1997: 23-24) Yükseköğretimde hizmet alanları "üniversite değerlendiricileri” adı altında ele 
alan Owlia ve Aspinwall (1996) ürün ve hizmete yönelik kalite unsurlarını ve bu kalite unsurlarının hedef müşterilerini aşağıdaki gibi belirlemişlerdir(Owlia ve Aspinwall, 1996: 19).

Tablo 1. Yüksek Öğretimde Kalite Unsurları ve Müșterileri

\begin{tabular}{|c|c|c|}
\hline \multicolumn{2}{|c|}{ Yükseköğretimde Kalite Unsurları } & Müşteriler \\
\hline Somut Unsurlar & $\begin{array}{l}\text { Yeterli Donanım ve Tesisler } \\
\text { Modern Donanım ve Tesisler } \\
\text { Ulaşım Kolaylı̆̆ } \\
\text { Güzel Çevre } \\
\text { Destek Hizmetler (Barınma, spor, } \\
\text { sosyal hizmetler) }\end{array}$ & $\begin{array}{l}\text { Ögrenciler } \\
\text { Akademik Personel }\end{array}$ \\
\hline Yeterlilik & $\begin{array}{l}\text { Yeterli Akademik Personel } \\
\text { Nitelikler } \\
\text { Iletişim Becerisi }\end{array}$ & Ögrenciler \\
\hline Tutum & $\begin{array}{l}\text { Öğrencilerin ihtiyaçlarının } \\
\text { anlaşılması } \\
\text { Yardıma isteklilik } \\
\text { Yardım ve danışmanlık için } \\
\text { ulaşılabilirlik } \\
\text { Bireysel ilgi gösterme }\end{array}$ & Ögrenciler \\
\hline İçerik & $\begin{array}{l}\text { Programların öğrencilerin } \\
\text { gelecekteki işleriyle uygunluğu } \\
\text { Geçerlilik } \\
\text { Bilgisayar kullanımı } \\
\text { Iletişim becerisi ve takım } \\
\text { çalışması }\end{array}$ & $\begin{array}{l}\text { Öğrenciler } \\
\text { Akademik Personel } \\
\text { Çalışanlar }\end{array}$ \\
\hline Sunum & $\begin{array}{l}\text { Etkili sunum } \\
\text { Tutarlılık } \\
\text { Sinavların tarafsızlı̆̆l } \\
\ddot{O} \breve{g r e n c i l e r d e n ~ g e r i b i l d i r i m ~} \\
\ddot{O} \breve{g r e n c i l e r i n ~ c e s a r e t l e n d i r i l m e s i ~}\end{array}$ & Öğrenciler \\
\hline Güvenilirlik & $\begin{array}{l}\text { Güvenilirlik } \\
\text { Geçerli ödüller verme } \\
\text { Sözünde durma } \\
\text { Şikâyetleri değerlendirme, } \\
\text { Problemleri çözme }\end{array}$ & $\begin{array}{l}\text { Öğrenciler } \\
\text { Akademik Personel } \\
\text { Çallşanlar }\end{array}$ \\
\hline
\end{tabular}

Kaynak: (Owlia ve Aspinwall, 1996: 19)

Tabloda yer alan haliyle ele alındığında hizmet kalitesi üniversitelerde pek çok alanda uygulanabilir. Bu alanlar, üniversitelerin somut hizmet alanlarından soyut hizmet alanlarına kadar sıralanabilir. Örnek olarak üniversitelerin sahip olduğu fiziki alan, altyapı yeterlilikleri, donanımlı kampus ortamı, öğrenci memnuniyetinin sunulan hizmetlerle sağlanması, iç müşterilerin memnuniyeti, dış paydaşların memnuniyeti, yeterli ve nitelikli insan kaynağı verilebilir. Bu noktada İnsan kaynakları yönetimin en önemli fonksiyonlarından biri kaliteli çalışanların istihdam edilmesi şeklinde değerlendirilebilir.

Bu doğrultuda çalışanların seçimi, örgütsel devamlılık açısından önemli bir unsur olarak karşımıza çıkmaktadır. Gerçekten de işletmeye hizmet edecek personelin bulunması, işletmenin amaçları ile paralel düşünüldüğünde bambaşka bir alanı ifade etmektedir. Personel seçimi, insan kaynakları merkezinin önemli bir çalışma konusunu oluşturur ve bu süreç, mevcut eleman ihtiyaçlarının tespiti, bu ihtiyacın uygun yollar ve araçlarla duyurulması, başvuruların alınması, görüşmelerin yapılması ve uygun adayların işe yerleştirilmesini içerir (Fındıkçı, 2000:167). Personel seçmenin başlıca amacı çalışanlar ile işin gereklilikleri arasında dengeyi kurmak ve buna göre seçim yapmaktır. İşte bu noktada, adayların eğitimleri, yetenekleri, hobileri, kişilikleri incelenir ve uygun olan adaylar davet edilir (Boyraz, 2002). Devamlılık açısından, hizmet sunumu yapılan kişilere ulaşan doğrudan çalışanlardır. Bu bakımdan personel seçve ve işe yerleştirme önemli bir husustur.

Müşterilere sunulan değer, bir örgütün bütün bölümlerini ilgilendiren, müşterilerle ortaklık kurarak oluşturulan bir sürecin sonucudur. Müşterilerle kurulan doğru iletişim, ürün veya hizmetin tasarımından satışına kadar tüm alanlarda, karar alma sürecinde iletişimin ve geri bildirimin yoğun olarak kullanıldığı, müşteri memnuniyetini ve sadakatini arttırmaya yönelik iletişimdir. Günümüzde örgütler, ürün ya da hizmeti satın alacak müşteri bulmak yanında müşteriyi elde tutmak, sadakat ve bağllık sağlayabilmek için müşteri memnuniyetini rekabet edebilmek adına sağlamak zorundadır. Örgütler, faaliyetlerini sürdürürken tüketicilerinin memnuniyetini çalışanlarından sağladıkları destekle sağlamaktadırlar. Bu çerçevede kaliteli çalışanların varlığı, dış müşterilerin sürekliliği ve verimlilikleri ile doğru 
orantılıdır (Turgut, 2006: 30). Bu kapsamda, bir örgütün müşterilerine sunduğu hizmet kalitesinin çalışanları ile başladığını söylemek doğru olacaktır. Üniversitelerde de insan kaynakları fonksiyonunun yeri ve önemi gündeme gelecektir. Çalışmanın uygulama bölümünde insan kaynakları ile ilgili ortaya çıkan bulgular durumun ciddiyetini ortaya koymaktadir.

\section{4. Üniversitelere Yönelik Şikayetlerin Araştırılması}

\subsection{Araștırmanın Amacı ve Yöntemi}

$\mathrm{Bu}$ araştırmanın amacı, yükseköğretim alanında faaliyet gösteren kamu ve vakıf üniversitelerine yönelik şikayetlerin en fazla hangi alanlarda olduğunu tespit etmek, kamu ve vakıf üniversitelerinin şikayetlerini karşılaştırmaktır. Üniversitelerin temel faaliyet alanlarına ve fonksiyonlarına yönelik hizmet kalitesi açısından şikayetlerin içeriğini esas alarak görüş ve öneriler sunmaktır. Araştırmada analiz yöntemlerinden nitel analiz tekniği kullanılmıştır. Bütüncül bir yaklaşıma sahip olarak bilinen nitel analizi nicel analizden ayıran en önemli özellik algıların ortaya konması ve tümevarımcı bir özelliğe sahip olmasıdır (Külekçi, 2013:371). Veri toplama aracı olarak doküman analiziyle tümevarımcı olan b

elirli aşamaların izlendiği (Yılmaz, 2001:5). bu araştırmada içerik analizi uygulanmıştır. Bir şikayet aktarma ortamı olan "şikayetvar.com" sitesinde yer alan "eğitim" kategorisinin alt başlığında yer alan "üniversiteler" başlığı dikkate alınmış, bu başlık altındaki toplamda 422 şikayet, 15 Haziran 2015 tarihinde, siteye o tarihe kadar düşen 2015 y1lı şikayetleri dikkate alınarak incelenmiştir. Sitede, araştırmanın yapıldığı dönemde yer alan tüm şikayetler dikkate alınmış ve araştırmanın evrenini bu şekilde sitede yer alan 422 şikayet oluşturmuştur.

İçerik analizinde; sözel, yazılı ve diğer materyallerin içerdiği mesajı, anlam veya dilbilgisi açısından nesnel ve sistematik olarak sınıflandırma, sayılara dönüştürme ve çıkarımda bulunma yoluyla sosyal gerçeği araştırma söz konusudur (Tavşancıl ve Aslan, 2001: 22). İçerik analizi; iletilerin, açık ve görünen içeriğinin, nesnel, ölçülebilir ve doğrulanabilir bir açıklamasını yapabilmek amacıyla kullanılmaktadır.Buna göre "şikayetvar.com" sitesinde yer alan "eğitim" ana başlığının altında "üniversiteler" seçilmiş; bu üniversitelere yönelik şikayetler ;

1. Eğitim ve Öğretim faaliyetlerine yönelik şikayetler,

2. Teknoloji alanındaki şikayetler,

3. İnsan Kaynakları alanı şikayetleri,

4. Araştırma ve Geliştirme alanı şikayetleri,

5. Finansal faaliyetlerine yönelik şikayetler,

6. Destek Hizmetlerine yönelik şikayetler,

7. Diğer alana yönelik şikayetler şeklinde kategorilere ayrılmıştır.

Şikayetlerin yukarıda yer alan başlıklara göre sınıflandırılmaşında üniversitelerin eğitim ve öğretim faaliyet alanları dikkate alınmış, bu sınıflandırma araştırmacı tarafından faaliyet alanı geniş tutularak oluşturulmuştur. Üniversitelerin hizmet verdikleri temel alanlar dikkate alınarak belirlenen bu kategoriler, her bir kategori altında yer alan alt kategorilerle desteklenmiş ve kodlanmıştır. Kodlama yapıldıktan sonra elde edilen veriler SPSS paket programında sayısallaştırılmıştır. Ayrıca üniversitelerin "kamu veya vakıf üniversitesi” olarak türleri, kuruldukları şehirlere yönelik bilgiler de yüzdelik oranlarla belirtilmiştir. Son bölümde bulguları destekleyecek şekilde vakıf ve kamu üniversiteleri kıyaslanmış, bulgular görüş ve önerilerle desteklenmiştir

\subsection{Araştırmanın Bulguları}

Araştırmaya dahil edilen üniversitelere yönelik şikayetler incelendiğinde ve analiz edildiğinde aşağıdaki bulgulara ulaşılmıştır:

Tablo 2. Kurum Türlerine Göre Şikayet Edilen Üniversite Sayıları ve Oranları

\begin{tabular}{|l|c|c|}
\hline & \multicolumn{2}{|c|}{ Şikayet Edilen } \\
\hline Üniversiteler \\
\hline Vakıf üniversitesi $i$ Trekans & Yüzde \\
\hline Kamu üniversitesi & 119 & $\% 28,20$ \\
\hline Toplam & 303 & $\% 71,80$ \\
\hline
\end{tabular}

Araştırmada "şikayetvar.com” sitesinde yer alan 422 şikayet incelenmiş ve analiz edilmiş, bunlardan 303 şikayetin kamu üniversitesine; 119 şikayetin ise vakıf üniversitesine ait olduğu tespit edilmiştir. Buna göre şikayetlerin daha çok kamu üniversitelerine ait olduğu görülmektedir. Şikayetlerin daha çok kamu üniversitelerine yönelik olması, Türkiye' de kamu üniversitelerinin vakıf üniversitelerine göre fazla olmasından kaynaklanabilir. Bunun dışında kamu üniversitelerinden hizmet alan öğrencilerin sayısının da fazlalığından kaynaklanabilir. Çünkü Türkiye' de 2013-2014 Eğitim öğretim yılında öğrenim gören öğrenci sayıları, kamu üniversitelerinde 5089291 iken; vakıf üniversitelerinde 350 999' dur. ( Nisan 2014 YÖK Verileri, Aktaran: Çetinsaya, 2014: 68) Öğretim türü ve yükseköğretimde kurum türlerine göre öğrenci sayıları ile dağılım oranları ise şu şekildedir: 
Cevher, E. / Journal of Yasar University, 2016, 11/43, 163-171

Tablo 3. Türkiye'deki Kamu ve Vakıf Üniversitelerinin Öğrenci Sayıları

\begin{tabular}{|c|c|c|c|c|}
\hline & \multicolumn{2}{|c|}{ Kamu Üniversiteleri } & \multicolumn{2}{|c|}{ Vakıf Üniversiteleri } \\
\hline Programlar & $\begin{array}{c}\text { Toplam } \\
\text { Sayt }\end{array}$ & $\begin{array}{c}\text { Toplam } \\
\text { Yüzde }\end{array}$ & $\begin{array}{c}\text { Toplam } \\
\text { Sayı }\end{array}$ & $\begin{array}{c}\text { Toplam } \\
\text { Yüzde }\end{array}$ \\
\hline Ön lisans & 1683044 & $\% 30,9$ & 57418 & $\% 1,1$ \\
\hline Lisans & 3139516 & $\% 57,6$ & 231172 & $\% 4,2$ \\
\hline Lisans üstü & 266731 & $\% 4,9$ & 62409 & $\% 1,1$ \\
\hline Genel Toplam & 5089291 & $\% 93,4$ & 350999 & $\% 6,4$ \\
\hline
\end{tabular}

Kaynak: Gökhan Çetinsaya, Büyüme Kalite Uluslararasılaşma Türkiye Yükseköğretimi İçin Bir Yol Haritası, Haziran 2014, s. 68

Tablo 4. Araştırmada Yer Alan Üniversitelerin Kuruluş Yerleri

\begin{tabular}{|l|c|c|c|c|}
\hline & \multicolumn{2}{|c|}{ Kamu Üniversiteleri } & \multicolumn{2}{c|}{ Vakuf Üniversiteleri } \\
\hline Şehirler & Frekans & Yüzde & Frekans & Yüzde \\
\hline Istanbul & 46 & $\% 15,2$ & 111 & $\% 93,3$ \\
\hline Ankara & 20 & $\% 6,6$ & 2 & $\% 1,7$ \\
\hline Izmir & 4 & $\% 1,3$ & 0 & $\% 0$ \\
\hline Bursa & 0 & $\% 0$ & 0 & $\% 0$ \\
\hline Konya & 0 & $\% 0$ & 0 & $\% 0$ \\
\hline Eskişehir & 134 & $\% 44,2$ & 0 & $\% 0$ \\
\hline Diğer & 99 & $\% 32,7$ & 6 & $\% 5,0$ \\
\hline Toplam & $\mathbf{3 0 3}$ & $\mathbf{\% 1 0 0 , 0}$ & $\mathbf{1 1 9}$ & $\mathbf{\% 1 0 0 , 0}$ \\
\hline
\end{tabular}

Araştırmada şikayet edilen üniversitelerin kuruldukları şehirlere bakıldığında en fazla şikayetin kamu üniversitelerinde; \% 44,2 oranında Eskişehir' de kurulu üniversitelere ait olduğu; vakıf üniversitelerinde ise \% 93,3 oranında İstanbul merkezli üniversitelere ait olduğu tespit edilmiştir. Kamu üniversitelerinde en yüksek oranı; \% 32,7 ile Anadolu'daki üniversiteler (diğer iller); \% 15,2 ile de İstanbul merkezli üniversiteler takip etmektedir. Burada özellikle şunu belirtmekte fayda görülmektedir. Eskişehir merkezli üniversiteler arasında araştırmaya Anadolu Üniversitesi de dahil edilmiştir. Anadolu Üniversitesinin gerek örgün öğretimi ve gerekse de açıöğretimi dikkate alındığında bu oranın Eskişehir' de en yüksek çıkması normal görülebilir. Şikayetlerde daha çok 'Açıköğretim Fakültesi” yer almaktadır. Bunun dışında vakıf üniversitelerinin daha çok İstanbul merkezli olması nedeniyle böyle bir oranın bu şehirde fazla çıkması da söz konusu olabilir. Çünkü vakıf üniversiteleri sayısının en fazla olduğu il İstanbul' dur. İstanbul'da toplam 38 vakıf üniversitesi bulunmaktadır. (www.yok.gov.tr; Erişim: 18.03.2015)

Tablo 4. Kamu ve Vakıf Üniversiteleri Şikayet Alanları

\begin{tabular}{|l|c|c|l|c|c|}
\hline & \multicolumn{2}{|c|}{ Kamu Üniversiteleri } & \multicolumn{2}{c|}{ Vakif Üniversiteleri } \\
\hline $\begin{array}{l}\text { Tüm Şikayet } \\
\text { Alanlari }\end{array}$ & Frekans & Yüzde & $\begin{array}{l}\text { Tüm Şikayet } \\
\text { Alanlari }\end{array}$ & Frekans & Yüzde \\
\hline Eğitim Ögretim & 134 & $\% 44,2$ & $\begin{array}{l}\text { Ĕgitim ve } \\
\text { Ögretim }\end{array}$ & 35 & $\% 29,4$ \\
\hline İnsan Kaynaklart & 54 & $\% 17,8$ & Finansman & 34 & $\% 28,6$ \\
\hline Teknoloji & 49 & $\% 16,2$ & İnsan Kaynaklart & 26 & $\% 21,8$ \\
\hline Finansman & 33 & $\% 10,9$ & Teknoloji & 14 & $\% 11,8$ \\
\hline Destek Hizmetleri & 16 & $\% 5,3$ & Destek Hizmetleri & 7 & $\% 5,9$ \\
\hline Diğer Konular & 16 & $\% 5,3$ & Diğer Konular & 3 & $\% 2,5$ \\
\hline Ar-Ge & 1 & $\% 0,3$ & Ar-Ge & 0 & $\% 0$ \\
\hline Toplam & $\mathbf{3 0 3}$ & $\mathbf{\% 1 0 0}$ & Toplam & $\mathbf{1 0 9}$ & $\mathbf{\% 1 0 0}$ \\
\hline
\end{tabular}

Tablo 4' e bakıldığında araştırmaya dahil edilen kamu üniversitelerinin şikayetlerinin \% 44,2 oranında "eğitim ve öğretim" alanında; vakıf üniversitelerinin şikayetlerinin ise \% 29,4 oranında yine "eğitim ve öğretim" alanında olduğu görülmektedir. Buna göre kamu üniversitelerinin ve vakıf üniversitelerinin en çok şikayet aldıkları alanlar "eğitim ve öğretim" alanıdır. Kamu üniversitelerinde diğer şikayet konuları sırasıyla \% 17,8 oranında insan kaynakları, \% 16,2 oranında teknoloji; \% 10,9 oranında ise finansman alanındadır. Vakıf üniversitelerinde ise bu sıralama farklılaşmaktadır. \% 28,6 oranında finansman konusunda şikayetler ikinci sırada iken; \% 21,8 oranında insan kaynakları; \% 11,8 oranında teknoloji alanında şikayetler bulunmaktadır. Buna göre kamu üniversitelerinde şikâyete konu olan ikinci faaliyet alanı insan kaynakları iken; vakıf üniversitelerinde finansal faaliyetler yer almaktadır. Tablo 4 ten sonra yer alan tablolarda üniversitelerin bu faaliyet alanlarına yönelik şikayet konularının içeriğine yer verilmiştir. 
Tablo 5. Eğitim ve Öğretim Faaliyetlerine Yönelik Şikayet Oranları

\begin{tabular}{|c|c|c|c|c|}
\hline & \multicolumn{2}{|c|}{ Кати Üniversiteleri } & \multicolumn{2}{|c|}{ Vakıf Üniversiteleri } \\
\hline Ĕ̆itim-Ö̈̆gretim Alanı & Frekans & Yüzde & Frekans & Yüzde \\
\hline Sinavlar ve not sistemi & 71 & $\% 23,4$ & 8 & $\% 6,7$ \\
\hline Diploma ve sertifika & 17 & $\% 5,6$ & 8 & $\% 6,7$ \\
\hline Ders materyali & 15 & $\% 5,0$ & 1 & $\% 0,8$ \\
\hline Kayit işlemleri & 13 & $\% 4,3$ & 6 & $\% 5,0$ \\
\hline Ders programi & 11 & $\% 3,6$ & 5 & $\% 4,2$ \\
\hline Yatay ve dikey geçiş & 4 & $\% 1,3$ & 2 & $\% 1,7$ \\
\hline Ders seçim işlemleri & 1 & $\% 0,3$ & 2 & $\% 1,7$ \\
\hline Öğrenci değişim işlemleri & 1 & $\% 0,3$ & 0 & $\% 0$ \\
\hline Yandal ve çiftdal işlemleri & 1 & $\% 0,3$ & 3 & $\% 2,5$ \\
\hline Toplam & 134 & $\% 44,2$ & 35 & $\% 29,4$ \\
\hline
\end{tabular}

Araştırmada eğitim-öğretim alanında incelenen şikayetlere bakıldığında; kamu üniversitelerinde \% 23,4 oranında "sınavlar ve not sistemi" şikayetleri en yüksek paya sahiptir. Bunu izleyen şikayet oranları ise; \% 5,6 ile "diploma ve sertifika" \% 5 oranında "ders materyali" \% 4,3 oranında da "kayıt işlemleri” konularındadır. Ders programı, yatay ve dikey geçiş, ders seçme işlemleri, öğrenci değişim hareketi, yandal ve çiftdal konularında da şikayetler bulunmaktadır. Sınavlar ve not sisteminde yine şikayetler ele alındığında sınavlarla ilgili şikayetlerin Eskişehir Anadolu Üniversitesi Açıköğretim Fakültesi sınavlarına yönelik olduğu tespit edilmiştir. Vakıf üniversitelerinin eğitim öğretim alanındaki faaliyetlerine yönelik şikayetlerinin ise \% 6,7 oranında "Sınavlar ve Not sistemi ve diploma/ sertifika" konusunda olduğu tespit edilmiştir. \% 5 oranında kayıt işlemleri \% 2,5 oranında da yandal ve çiftdal işlemleri ile ilgili şikayetler bulunmaktadır. Hem kamu üniversiteleri hem de vakıf üniversitelerinde öğrencilerin çoğunlukla şikayet ettiği konulardan biri "sınavlar ve not sistemi” olmuştur. Ancak kurum tipleri kıyaslandığında kamu üniversitelerine yönelik şikayet oranları fazladır. Bunda da özellikle "açıköğretim fakültesi sınavları ve notları” konusu gündeme getirilmiştir. Bunun dışında "sınıf ortalamaları, çan eğrisi, sınav uygulamaları, sınav tarihleri”" dile getirilen şikayetler arasındadır. Bu alanda dikkat çeken durum, vakıf üniversiteleri şikayetlerinin sayıca azlığıdır.

Tablo 5. Teknoloji Alanına Yönelik Şikayet Oranları

\begin{tabular}{|l|c|c|c|c|}
\hline & \multicolumn{2}{|c|}{ Kamu Üniversiteleri } & \multicolumn{2}{c|}{ Vakif Üniversiteleri } \\
\hline Teknoloji alani & Frekans & Yüzde & Frekans & Yüzde \\
\hline Telefon Erişim & 25 & $\% 8,3$ & 12 & $\% 10,1$ \\
\hline Online Işlemler & 14 & $\% 4,6$ & 1 & $\% 0,8$ \\
\hline Web Erişim & 8 & $\% 2,6$ & 0 & $\% 0$ \\
\hline Web Içerik & 2 & $\% 0,7$ & 1 & $\% 0,8$ \\
\hline Toplam & $\mathbf{4 9}$ & $\mathbf{\% ~} \mathbf{1 6 , 2}$ & $\mathbf{1 4}$ & $\mathbf{\% ~ 1 1 , 8}$ \\
\hline
\end{tabular}

Tablo 5 incelendiğinde kamu üniversitelerinin teknoloji alanına yönelik şikayetlerinin \% 8,3 oranında "telefonla erişim" ve \% 4,6 oranında "online işlemler" konusunda olduğu tespit edilmiştir. Bu oranları sırasıyla "web erişim" ve "web içerik" konuları takip etmiştir. Vakıf üniversitelerinde de şikayetler benzer şekilde \% 10, 1 oranında "telefonla erişim" konusunda tespit edilmiştir. Buna göre hem kamu hem de vakıf üniversitelerinde "telefonla erişim” konusu temel şikayet konuları içerisindedir. Üniversitelerde santral hizmetlerinin iyileştirilmesi bu noktada gündeme gelebilir. Operatör hizmetlerinin etkin şekilde sunulması, telefonlara cevap verilmesi, dahili hatlara yönlendirmenin olması bu sorunları giderebilir. Çünkü telefonla şikayetlerin içeriğine bakıldığında şikayette bulunanlar daha çok "telefonlara yanıt alamama, telefonla ilgili birimlere ulaşamama" gibi konuları gündeme getirmişlerdir. Kamu üniversitelerinde online işlemler konusunda dile getirilen şikayetlerin içeriği ise "kayıt işlemleri ve ders kayıtları" konusunda olmuştur. Birim web sayfalarına ulaşamama veya online hizmetlerin yürütüldüğü sayfalarda oluşan hatalar ise web erişimine yönelik şikayetlerden bazılarıdır. Web içeriği konusunda da üniversitelerin kullanıcılarına sunduğu web içeriklerinin karmaşık yapısına ilişkindir. Ancak yapılan bir araştırmada kamu üniversitelerinin web sayfaları kullanım alanında "kamu kurumları web sayfaları hazırlama kılavuzu" na uydukları, kılavuzda yer alan asgari standartların çoğunu sağladıkları tespit edilmiştir. (Cevher, 2015: 400) 
Cevher, E. / Journal of Yasar University, 2016, 11/43, 163-171

Tablo 6. Finansal Alana Yönelik Şikayet Oranları

\begin{tabular}{|c|c|c|c|c|}
\hline & \multicolumn{2}{|c|}{ Кати Üniversiteleri } & \multicolumn{2}{|c|}{ Vakıf Üniversiteleri } \\
\hline Finansman Alant & Frekans & Yüzde & Frekans & Yüzde \\
\hline$\ddot{U}$ cret ve Ödemeler & 28 & $\% 9,2$ & 26 & $\% 21,8$ \\
\hline Ücret veya Senet İade & 3 & $\% 1,0$ & 3 & $\% 2,5$ \\
\hline Hediye ve Ödüllendirme & 1 & $\% 0,3$ & 0 & $\% 0$ \\
\hline Burs veya Indirimler & 1 & $\% 0,3$ & 5 & $\% 4,2$ \\
\hline Toplam & 33 & $\% 10,8$ & 34 & $\% 28,6$ \\
\hline
\end{tabular}

Tablo 6 incelendiğinde üniversitelerin finansal faaliyetlerine yönelik şikayetlerin kamu üniversitelerinde $\% 9,2$ oranında; vakıf üniversitelerinde ise \% 21,8 oranında "ücret ve ödemeler" konusunda olduğu görülmektedir. Ücret ve ödemeler her iki üniversite tipinde de temel şikayet konusudur. Vakıf üniversitelerinde \% 4,2 oranında "burs veya indirimler" ile ilgili şikayetler de söz konusudur. Ücret iade veya senet iade konularında ise hem kamu hem de vakıf üniversitelerine yönelik aynı oranda şikayet söz konusudur. Şikayetlerin içeriğinde ise vakıf üniversiteleri için ücret artışları, ücret iadeleri, burs ve burs taahhütleri vb. konular yer almaktadır.

Hem kamu hem de vakıf üniversiteleri için ücret konusunun öğrenci katkı paylarından kaynaklandığı düşünülebilir. Ödemelere yönelik şikayetler, daha çok artan ücretlerle ilgilidir. Vakıf üniversitelerinde bu oranın yüksek çıkması bu üniversitelerin özel üniversite gibi algılanmasından kaynaklanmaktadır. Çünkü Anayasanın 130. Maddesinde kazanç amacı gütmeme öngörülmesine rağmen, vakıf yükseköğretim kurumları özel üniversite şeklinde algılanmakta, hatta kimi kurumlarda öğrenim ücretleri ve programlar konusunda özel piyasa koşullarına benzer politikalar izlenmektedir (Batırel, 1997: 54).

Tablo 7. İnsan Kaynaklarına Yönelik Şikayet Oranları

\begin{tabular}{|l|c|c|c|c|}
\hline & \multicolumn{2}{|c|}{ Kamu Üniversiteleri } & \multicolumn{2}{c|}{ Vakıf Üniversiteleri } \\
\hline İnsan Kaynakları Alanı & Frekans & Yüzde & Frekans & Yüzde \\
\hline Personel Davranışı & 14 & $\% 4,6$ & 13 & $\% 10,9$ \\
\hline Akademik Personel & 11 & $\% 3,6$ & 4 & $\% 3,4$ \\
\hline Telefonda Bilgilendirme & 14 & $\% 4,6$ & 3 & $\% 2,5$ \\
\hline Telefonda Personel Davranışı & 7 & $\% 2,3$ & 2 & $\% 1,7$ \\
\hline Telefonda Sorun Çözme & 7 & $\% 2,3$ & 4 & $\% 3,4$ \\
\hline Rehberlik Hizmetleri & 1 & $\% 0,3$ & 0 & $\% 0$ \\
\hline Toplam & $\mathbf{5 4}$ & $\mathbf{\% ~} \mathbf{1 7 , 8}$ & $\mathbf{2 6}$ & $\mathbf{\% ~ 2 1 , 8}$ \\
\hline
\end{tabular}

Üniversitelerin insan kaynaklarına yönelik şikayetleri incelendiğinde ise kamu üniversitelerinde \% 4,6 oranında "personel davranışı ve telefonda bilgilendirme" temel şikayet konularıdır. Vakıf üniversitelerinde de \% 10,9 oranında "personel davranışı" şikayet konusu olmuştur. Buna göre öğrencilere sunulan hizmetlerde personel davranışları en yüksek oranda şikayete konu olmuştur. Özellikle öğrencilerin hizmet aldıkları "öğrenci işleri” birimine yönelik bu şikayetler dile getirilmiştir. Transkript, diploma vb işlemlerin yapılmasında öğrenciler "güleryüzlü hizmet, yeterli bilgi alamama, eksik bilgilendirme" gibi konuları şikayet unsuru olarak yazmışlardır. Akademik personelin şikayet konusu olduğu kamu üniversitelerinde şikayetin içeriği "akademik personelin deneyimsizliği, not verme sistemi, davranışları" unsurlarından oluşmaktadır. Yine hem kamu hem de vakıf üniversitelerine yönelik "telefonda bilgilendirme ve telefonda personel davranışı” şikayetleri "eksik bilgi verme, bilgi vermeme, sert üslup, telefonda herhangi bir bilgiye ulaşamama" gibi nedenlerden oluşmuştur.

Tablo 8. Araştırma ve Geliştirme Alanına Yönelik Şikayet Oranları

\begin{tabular}{|l|c|c|c|c|}
\hline & \multicolumn{2}{|c|}{ Kamu Üniversiteleri } & \multicolumn{2}{c|}{ Vakıf Üniversiteleri } \\
\hline Araştirma Geliştirme Alanı & Frekans & Yüzde & Frekans & Yüzde \\
\hline Kütüphane & 1 & $\% 0,3$ & 0 & $\% 0$ \\
\hline Toplam & 1 & $\% 0,3$ & 0 & $\% 0$ \\
\hline
\end{tabular}

Araştırma ve geliştirmeye yönelik şikayet bulgusuna sadece kamu üniversitelerinde \% 0,3 oranında "kütüphane hizmetleri" alanında yer verilmiştir. Vakıf üniversitelerinin araştırma ve geliştirme faaliyetlerine yönelik ise şikayet bulgusuna rastlanmamıştır. Dile getirilen şikayet ise kitap yetersizliğine yönelik olmuştur. Bu şikayetten yola çıkılarak, üniversitelerde etkin ve güncel bir veri tabanı sisteminin oluşturulması önerilebilir. Kitap sayılarının artırılması, online veritabanlarının geliştirilmesi, dergi üyeliklerinin artırılması özellikle araştırmacı akademisyen ve öğrencilere yönelik kaliteli hizmetin önünü açacaktır. 
Cevher, E. / Journal of Yasar University, 2016, 11/43, 163-171

Tablo 9. Destek Hizmetlerine Yönelik Şikayet Oranları

\begin{tabular}{|l|c|c|c|c|}
\hline & \multicolumn{2}{|c|}{ Kamu Üniversiteleri } & \multicolumn{2}{c|}{ Vakıf Üniversiteleri } \\
\hline Destek Hizmetler & Frekans & Yüzde & Frekans & Yüzde \\
\hline Güvenlik & 3 & $\% 1,0$ & 0 & $\% 0$ \\
\hline Yurt Misafirhane & 3 & $\% 1,0$ & 0 & $\% 0$ \\
\hline Spor Tesisleri & 3 & $\% 1,0$ & 0 & $\% 0$ \\
\hline Yemek & 2 & $\% 0,7$ & 1 & $\% 0,8$ \\
\hline Temizlik Hijyen & 2 & $\% 0,7$ & 1 & $\% 0,8$ \\
\hline Araç Girişi Otopark & 1 & $\% 0,3$ & 1 & $\% 0,8$ \\
\hline Kantin Kafeterya & 1 & $\% 0,3$ & 3 & $\% 2,5$ \\
\hline Ulaşım Servis & 1 & $\% 0,3$ & 1 & $\% 0,8$ \\
\hline Toplam & $\mathbf{1 6}$ & $\mathbf{\% 5 , 3}$ & $\mathbf{7}$ & $\mathbf{\% ~ 5 , 9}$ \\
\hline
\end{tabular}

Kamu ve Vakıf üniversitelerinde destek hizmetlere yönelik şikayetler incelendiğinde ise kamu üniversitelerinde \% 1 oranında "güvenlik, yurt ve misafirhane, spor tesisleri" ile ilgili şikayetler söz konusudur. Vakıf üniversitelerinde ise \% 2,5 oranında "kantin kafeterya" hizmetleri konusu şikayet edilmiştir. Buna göre kamu ve vakıf üniversitelerinin destek hizmetleri alanındaki şikayetleri en yüksek oran sırlamasında farklılaşmaktadır. Yemek, temizlik ve hijyen, otopark, ulaşım ve servis konuları da her iki üniversite tipinde şikayete konu olmuştur.

Tablo 10. Diğer Alanlara Yönelik Şikayet Oranları

\begin{tabular}{|l|c|c|c|c|}
\hline & \multicolumn{2}{|c|}{ Kamu Üniversiteleri } & \multicolumn{2}{c|}{ Vakıf Üniversiteleri } \\
\hline Diğer Alan & Frekans & Yüzde & Frekans & Yüzde \\
\hline Diğer & 16 & $\% 5,3$ & 3 & $\% 2,5$ \\
\hline Toplam & $\mathbf{1 6}$ & $\mathbf{\% ~ 5 , 3}$ & $\mathbf{3}$ & $\mathbf{\% ~ 2 , 5}$ \\
\hline
\end{tabular}

Diğer konuları içeren ve belirli kategorilerle doğrudan bağlantısı olmayana şikayetlerin oranları ise kamu üniversitelerinde \% 5,3 oranında; vakıf üniversitelerinde ise \% 2,5 oranında ortaya çıkmıştır. Diğer konular başlığı, üniversitelerin temel faaliyet alanları ile ilişkilendirilemediği için böyle bir başlık tercih edilmiş ve veri olarak değerlendirilmiştir.

\section{Sonuç}

Çalışmanın araştırma aşamasına yönelik üniversitelerin temel hizmet alanları şikayetleri incelendiğinde elde edilen bulgular en yüksek oranda hem kamu üniversiteleri hem de vakıf üniversiteleri açısından "eğitim-öğretim alanı" olarak ortaya çıkmıştır. Eğitim ve öğretim alanında ise "sınavlar ve not sistemi" "diploma ve sertifika" "kayıt işlemleri" "ders programı" konuları gerek kamu üniversiteleri gerekse vakıf üniversiteleri açısından temel şikayet konularını oluşturmuştur.

Kamu üniversiteleri için insan kaynakları alanı şikayetleri ,vakıf üniversiteleri için ise finansal faaliyetlere yönelik şikayetler ikinci sırada yer almıştır. İnsan kaynakları konusunda kamu üniversiteleri ve vakıf üniversitelerine yönelik en fazla gündeme getirilen şikayet "personel davranışı” şeklinde ortaya çıkmıştır. Finansal faaliyetler alanında ise her iki üniversite tipi için "ücret ve ödemeler" temel şikayet konuları arasında en yüksek orana sahiptir. Teknolojik altyapıya yönelik şikayetler ise kamu ve vakıf üniversitelerinde "telefonla erişim" konusunda olmuştur. Araştırma ve geliştirme faaliyetlerine yönelik hizmetlerde üniversitelerin öğrenciye bakan tarafında sadece kamu üniversitelerinde "kütüphane hizmetleri" ne yönelik şikayet bulgusuna rastlanmıştır. Destek hizmetler alanında ise kamu üniversiteleri açısından "güvenlik, yurt ve misafirhane, spor tesisleri” en yüksek oranda şikayet konusu iken, vakıf üniversitelerinde en yüksek şikayet oranı "kantin ve kafeterya" konusunda olmuştur.

Tüm bu veriler dikkate alındığında hem kamu üniversiteleri hem de vakıf üniversiteleri açısından eğitim öğretim alanında sınavlar ve not sistemi konusunda iyileştirmelerin yapılması önerilebilir. Sınav yönetmeliklerinde yapılacak değişiklikler ile Avrupa kredi transfer sistemi gibi konularının gündeme alınması söz konusu olabilir. Öğrenciye sunulan hizmetlerde temel aktörlerden olan "akademik personel" konusu da insan kaynakları alanında dikkate alınacak konulardan olabilir. Özellikle deneyimli ve nitelikli akademik personelin liyakat usulüne uygun şekilde seçilmesi ve kadroların bu şekilde oluşturulması sağlanabilir. Yine öğrenciyle doğrudan iletişim kuranların başında yer alan idari personelin de dikkate alınması önemli bir husustur. Özellikle hizmet içi eğitimlerle desteklenecek idari personel sunulan hizmetlerde daha verimli hale gelebilir. Finans alanında , özellikle ücret ve ödemelerle ilgili "burslar, katkı payları" konusunda yapılacak düzenlemelerle öğrencilerin memnuniyeti sağlanabilir. Vakıf üniversiteleri katkı paylarının düşürülmesi, başarılı öğrencilere sağlanan burs oranlarının artırılması söz konusu olabilir. Bunlar dışında öğrencilere sunulan destek hizmetlerinde "güvenlik, ulaşım, yemek hizmetleri, barınma, temizlik ve hijyen” konularının da tüm üniversiteler açısından dikkate alınması hizmet kalitesini artıracaktır. 


\section{KAYNAKÇA}

Batırel, Faruk. 1994. Vakıf Üniversiteleri Kamu Üniversiteleri Entegrasyonu, Başbakanlık Basımevi, Ankara.

Boyraz, Ali Murat. 2002. Personel Seçim Sürecinde Psikoteknik Yöntemin Kullanılması: Askeri Organizasyonlara Dönük Bir Uygulama., Yayınlanmamış Yüksek Lisans Tezi, İstanbul Üniversitesi.

Ceylan, Memduh. 1997. "Eğitimde Toplam Kalite Yönetimi ve Müşteri Memnuniyeti” Kuram ve Uygulamada Eğitim Yönetimi Dergisi, 9(2), 23-30.

Cevher, Ezgi. 2015. "Kamu Üniversiteleri Web Sayfalarının Kullanılabilirliğinin İçerik Analizi İle İncelenmesi”, Gaziantep Üniversitesi Sosyal Bilimler Dergisi, 14(2), 387-402.

Çavdar, Ertuğrul.2009. "Yükseköğretimde Hizmet Kalitesi Unsurları ve Bir Uygulama", Niğde Üniversitesi IIIBF Dergisi, 2009, 2(2), 100-115.

Çetinsaya Gökhan (2014) Büyüme, Kalite, Uluslararasılaşma: Türkiye Yükseköğretimi İçin Bir Yol Haritası, Yükseköğretim Kurulu Yayın No. 2014/ 2

Demir, Hulusi ve Gümüşoğlu, Şevkinaz. 1998. Üretim İşlemler Yönetimi, Genişletilmiş 5. Baskı, İstanbul, Beta Basım Yayın Dağıtım A.Ş.,

Fındıkçı, İlhami. 2000. İnsan Kaynakları Yönetimi, Yönetim Dizisi, Alfa Basım Yayın.

Hepkul, Ayşe. ve Kağnıcıŏlu, Hakan. 1996. "Veri Tabanlı Pazarlama”, Pazarlama Dünyası, 6(34), Temmuz 1996, $27-$ 33.

Külekçi,Ebru. 2013. “4+4+4 Eğitim sistemi Kapsamında Birleştirilmiş Sınıf Uygulamasına İlişkin Öğretmen Görüşlerinin Değerlendirilmesi”, Ĕgitim ve Öğretim Araştırmaları Dergisi Journal of Research in Education and Teaching, 2 (2), 2013.

Owlia Mohammed. ve Aspinwall Elaine. 1996 . "Quality Assurance In Education A Framework Fort He Dinemsions Of The Quality Higher Education", Quality Assurance in Education , 4 (2), 12-20. ss.

Prahalad, Cames ve Hamel, Gary. 1996. Geleceği Kazanmak (Çev: Zülfü Dicleli), 1996, İstanbul, İnkılap Kitabevi,

Tavşancıl, Ezel ve Aslan, Esra. 2001. İçerik Analizi ve Uygulama Örnekleri, Epsilon Yayınları, İstanbul.

Turgut, Ahmet 2006. İlişki Yönetiminde İç Ve D1ş Müşterinin Önemi, Niğde T.S.O Ticaret Dergisi, Eylül Ekim

Yıldırım Ali. ve Şimşek H., (2004). Sosyal Bilimlerde Nitel Araştırma Yöntemleri, Seçkin Yayıncılık, 4. Basım, Ankara.

Yilmaz, Serap. 2011. "Ilköğretim Dördüncü Sınıf Öğrencilerinin Birlikte Çalışmaya İlişkin Algıları", Ahi Evran Üniversitesi Ĕ̆itim Fakültesi Dergisi., 12( 1),1-14.ss.

Zeithaml, Valerie, Parasuraman, A. and Berry, Lilly. 1990. Delivering Service Quality, Free Press, New York, NY. 